\title{
ATLANTIC UNIVERSITIES GEOLOGICAL CONFERENCE 1998
}

\author{
October 15-17, 1998
}

\section{Abstracts}

Conference hosted by:

\author{
Fletcher Geology Club \\ Acadia University \\ Wolfville, Nova Scotia
}

Again this year, abstracts from the annual Atlantic Universities Geological Conference (AUGC) are published in "Atlantic Geology". This provides a permanent record of the abstracts, and also focuses attention on the excellent quality of these presentations and the interesting and varied geoscience that they cover.

The Editors 


\title{
Form and function of the graptolite prosicula, and its application to biostratigraphic and evolutionary studies
}

\author{
Lorna Clarke \\ Department of Biology, Memorial University of Newfoundland, St. John's, Newfoundland A1B 3X5, Canada
}

The graptolite prosicula is the first ontogenetic structure to be secreted by the graptolite zooid, and has implications for classification and biostratigraphic studies. Using graptolites of Ordovician age, chemically isolated from rocks of western Newfoundland, it is here shown that prosiculae have characteristic morphological structures and the potential both to date the rocks in which they are contained and to in some cases permit identification to generic or specific level.

Morphological features include the presence or absence of a spiral line and diaphragm, the presence and complexity of longitudinal rods, width of nema, and overall prosicular form. In this study, it is concluded that graptolites possessing a wide nema, diaphragm, and a clearly visible spiral line are all
Tremadoc (earliest Ordovician) in age, while those with a prominent spiral line and many longitudinal rods arranged in pairs are late Tremadoc. Arenig graptolites characteristically do not show a visible spiral line or a diaphragm, and have only a few longitudinal rods which run parallel along the prosicular length.

The results of this study may also have relevance to subsurface biostratigraphy, particularly to oil exploration in the study areas. Subsurface exploration, using identifiable graptolite species, may be sufficient in determining if oil may be present in that area. In addition, these results suggest that additional research is justifiable to determine if the same morphological changes in graptolites occur in later strata (i.e., the Silurian).

\section{Thrusting of Horton Group over Windsor Group rocks, Cheverie, Nova Scotia}

\author{
Stanley K. Johnston \\ Department of Geology, Saint Mary's University, Halifax, Nova Scotia B3H 3JS, Canada
}

Strongly deformed Carboniferous rocks of the Horton and lower Windsor groups are exposed along the coastline of the Minas Basin from Cheverie Point towards Split Rock. In the past the distribution of units has been interpreted as resulting from high-angle faults to horst and graben structures. However, detailed mapping of this area shows that the Horton Bluff Formation (lower Horton Group) has been strongly deformed, when compared to the Cheverie Formation (upper Horton Group). Black shales and fine-grained grey sandstones of the Horton Bluff Formation show open to inclined tight folds with major fold axes trending northeast to southwest. Most folds are inclined to overturned to the southeast with associated northeast- to southwest-striking cleavage. Thrust and conjugate normal faultsare present. Red mudstone and sandstone of the Cheverie Formation are mildly deformed at Johnson Cove. Near the top of the formation at Cheverie Point, duplex and fault-propagation fold structures are seen. Laminated limestone and calcareous sandstone of the Macumber Formation (Windsor Group) are strongly folded and faulted throughout the entire study area. Pembroke Breccia (Windsor Group) is massively deformed with angular elongate blocks of the Macumber Formation. White gypsum and anhydrite of the Quarry Formation (Windsor Group) show anastomosing ductile (planar and linear) and brittle planar structures throughout. Interconnected diabase dykes and sills intrude only the Horton Bluff Formation; thin sections from dyke margins show that the intrusions cross-cut the tectonic fabric of the Horton Bluff host rocks. An uncomformable, normally faulted contact between Triassic sandstone and the Horton Bluff Formation, which truncates a diabase sill at Johnson Cove.

A re-interpretation of the data leads to a conclusion that low-angle thrust faulting placed Horton Bluff Formation strata over the Cheverie Formation and Windsor Group. Transpressional thrust faulting exposed along the coast of the Minas Basin reveals a possible relationship with the Cobequid-Chedabucto Fault System. Mesozoic extensional normal faulting reveals unconformable contacts of Triassic sandstone on top of shale and fine-grained sandstone of the Horton Bluff Formation.

\section{Production control in the Dunvegan Formation, west-central Alberta}

\author{
Therese Lynch \\ Department of Geology, St. Francis Xavier University, Antigonish, Nova Scotia B2G 2W5, Canada
}

The Dunvegan Formation is a deltaic sequence deposited in the Lower Cretaceous of west-central Alberta, bounded on the top by the Shaftesbury marine shale and on the bottom by the Kaskapau marine shale. The Hinton area is at the southeasternmost edge of the Dunvegan delta, so had relatively thin beds of sand. Despite this, the Dunvegan Formation produces very well in the Hinton area, with cumulative production of over $4 \mathrm{BCF}$ gas in one well, and $5 \mathrm{BCF}$ gas in another. The Findley area has good gas shows in the Dunvegan Formation, and the sands are thicker, but there is currently no production in the area due to lack of pipeline infrastructure. If it is found that the Findley area could have the potential to produce, it may be an area of future development. The objective of this project is to determine what is controlling the production in the Dunvegan Formation in the Hinton and Findley areas; whether it be due to primary porosity or fracturing as the result of thrust faulting. Determining what is controlling the production will give information on areas that have higher or lower potential for production.

In order to achieve the objective of the project and to 
pinpoint areas of exploration potential, both in the Hinton and Findley areas, the following steps were taken. The first step was to create a series of cross-sections in the Findley and Hinton areas to obtain an idea of which sands are producing and see whether the sands can be correlated over a large area. Contour maps of the stratigraphic and structural thicknesses of the sands of interest in both areas were done to show their regional distribution. The location of the producing wells was compared to the location of the thrust faults that cut through the area to see if there is a possible relationship between production and fracturing resulting from the faulting. It was found that the producing wells are in close proximity to the thrust faults. From this it was determined that production in the Hinton area is likely due to fracturing, and therefore areas of interest in the Findley area would be to the west of the thrust faults where the sands are repeated and fractured.

\title{
Sedimentology and paleoecology of the Upper Parrsboro Formation, Rams Head, Cumberland County, Nova Scotia
}

\author{
Beth McCarthy \\ Department of Geology, St. Francis Xavier University, Antigonish, Nova Scotia B2G 2W5, Canada
}

The Parrsboro Formation is Late Namurian to Early Westphalian $A$ in age and is located in northwestern Nova Scotia along the southern flank of the Maritimes Basin. The formation consists predominantly of clastic rocks varying from siltstone to conglomerate.

The Rams Head study section is located in the upper part of the Parrsboro Formation, approximately $16 \mathrm{~km}$ west of the town of Parrsboro. Continuous exposure of sedimentary strata at this locality occurs for hundreds of meters, and the orientation of the strata changes gradually from horizontal to vertical. It is within these strata that a treasure trove of fossils was discovered by a young boy in 1887 and sparked a renewed interest in the area. A detailed measured section of the strata shows that the clastic rocks at Rams Head consist predominately of red or grey fissile siltstone and red or grey medium-grained sandstone as well as minor interbedded 2 to $3 \mathrm{~cm}$ coalified layers. New fossil types discovered during this study together with the 1997 finding are predominantly from within two dominant sediment types. The fossils include very finely macerated plant matter to whole in situ tree trunks, beautifully preserved tetrapod trackways and horseshoe crab traces discovered during the course of this study. Large scale interference ripples and load casts were also found. The characteristics of the clastic rocks, fossils and sedimentary structures are important for interpreting paleoclimate, the origin of basin-fill, the creatures that lived in the area and how they interacted with their environment.

The Late Namurian to Early Westphalian A age of Rams Head is based on the occurrence of megaflora. Palynology samples taken from the two locations in the measured section may help better constrain the age of the section. The strata at Rams Head have a range in depositional environments. At the base of the section, well-drained paleosols and tetrapod trackway-impressed beds suggest subaerial exposure. The paleosol strata are sandwiched between the tabular crossstratified beds. These cross-stratified beds are indicative of shoaling sequences. Higher up in the section, mudstone and platy, planar sandstone are indicative of deposition in a deeper water lacustrine environment. These sediments are overlain by the tabular cross-stratified beds and subaerial sandstone, indicating a return to a shallower environment of deposition.

\section{Petrological and geochemical attributes of the Benjamin River porphyry Cu deposit, northeastern New Brunswick}

\author{
Kirsten McLaughlin \\ Department of Geology, University of New Brunswick, Fredericton, New Brunswick E3B 5A3, Canada
}

A mineralogical and multielement geochemical study was undertaken on the most mineralized cupolas of the Benjamin River porphyry $\mathrm{Cu}$ deposit in order to ascertain the controls on the $\mathrm{Cu}$ and Mo mineralization. The Benjamin River porphyry $\mathrm{Cu}$ deposit is located about $13 \mathrm{~km}$ south of Chaleur Bay in Restigouche County, New Brunswick. The Early Devonian intrusive phases that host most of the mineralization range from a tan coloured hypidiomorphic granodiorite that contains 8 to $15 \%$ biotite to a variably porphyritic variety. The host rocks are pink to red, feldspar-phyric rhyolite and fine-grained, dark grey, green and black mafic volcanic rock of the Middle Silurian Bryant Point Formation. The primary pyrite-chalcopyrite mineralization is dominantly disseminated within an alkalic-type alteration ( \pm phyllic) in varying proportion throughout the granodiorite, but to a lesser extent in mafic and felsic host rocks. The secondary mineralization is in the form of sulfide-rich pyrite-base-metal veins that cut disseminated mineralization. Molybdenite commonly occurs in secondary quartz-bearing veins. Crosscutting relationships are uncommon, but where present appear to indicate that the quartz veins were emplaced later than the sulfide veins. Weak pervasive propylitic alteration is superimposed on much of the host primary mineralization alteration, although some is vein controlled.

Drill core samples and existing pulp samples from drill core were selected from the variably mineralized and altered parts of the cupolas sampled. Microprobe analysis is planned on the biotite-alkali feldspar-magnetite assemblages from the unmineralized intrusive phases to the mineralized alkalic-type alteration to help ascertain the hydrothermal conditions for 
chalcopyrite mineralization. The drill core samples were assayed for $\mathrm{Cu}, \mathrm{Mo}$ and $\mathrm{Au}$ by Stairs Laboratory, Beresford, New Brunswick, in order to be compared to existing data. Major- and trace-element analysis of the pulps is to be performed by the pressed pellet X-Ray Fluorescence Spectrometry at Memorial University of Newfoundland. An additional eight samples were analysed using Inductively Coupled PlasmaMass Spectrometry for additional petrogenetically important elements. Preliminary analysis of the geochemical data indi- cates that the granodiorite phases are cogenetic and that they represent relatively depleted, calc-alkaline I-type intrusions. These geochemical attributes are similar to other Middle Devonian $\mathrm{Cu}$-mineralized intrusive systems in northern New Brunswick, as well as the porphyry hosting the mineralization at Mines Gaspe, Quebec; therefore, the Benjamin River $\mathrm{Cu}$ deposit is part of a much larger arc-like intrusive metallogenic province.

\title{
Structural and alteration history of a small gold deposit formed during D3 mylonitic deformation, Buffalo mine, Red Lake, Ontario
}

\author{
Neil Pettigrew ${ }^{1}$, Thomas Menard ${ }^{2}$, and John Spray ${ }^{1}$ \\ 'Department of Geology, University of New Brunswick, Fredericton, New Brunswick E3B 5A3, Canada \\ ${ }^{2}$ Department of Geology and Geophysics, University of Calgary, Calgary, Alberta T2N IN4, Canada
}

Detailed structural analysis of the Buffalo Deposit in the Archean Red Lake greenstone belt, northwestern Ontario, suggests that gold was localized during D3 mylonite-style deformation and associated retrograde metamorphism. The deposit is therefore younger than much larger deposits elsewhere in the belt. The deposit was mined from 1980 to 1982 and produced 1,656 troy ounces of gold at an average grade of 0.11 oz Au/ton. The mine was dewatered in October of 1998 by Claude Resources and is currently under production. The deposit is hosted by the $\sim 7 \mathrm{~km}$-diameter, $2718 \mathrm{Ma}$ Dome stock granodiorite and the ore occurs in quartz + tourmaline + sulphide veins and associated alteration zones.

Field work included detailed mapping at a scale of 1:24 of a well-exposed outcrop at the Buffalo deposit. Several basalt xenoliths up to tens of meters in size were incorporated into the stock at the Buffalo gold deposit which are aligned and sheared parallel to the contact. Aplite dikes intruded soon after crystallisation and are also highly deformed. These structures were subsequently crosscut by two generations of auriferous quartz + sulphide veins during a mylonitic M3 metamorphic event. The first generation of veins is small $(-3 \mathrm{~cm}$ or less wide), with a strike of $239^{\circ}$ and dipping $73^{\circ}$ north. These veins were crosscut by $\sim 10 \mathrm{~cm}$ wide veins with a strike of $119^{\circ}$ dipping $76^{\circ}$ south.

Most of the quartz in the second generation veins was replaced by tourmaline, and a $\sim 10 \mathrm{~cm}$ wide metasomatic aureole bleached the granodiorite to pink around the altered veins. This late boron metasomatic fluid also permeated the granodiorite at the Buffalo deposit and produced small $(1 \mathrm{~mm}$ or less wide) tourmaline-bearing black veinlets decorating all previous structural fabrics.

Fifty-four gold/silver assays and 23 whole rock samples were analysed; boron and sulphur content were also determined on select samples. Geochemical analysis indicates that the boron metasomatism surrounding the altered veins enriched the gold and sulphide mineralization with respect to the surrounding granodiorite. There is also a strong correlation between the degree of gold and sulphide mineralization throughout the Buffalo Deposit.

Compilation of structural fabrics in the Buffalo deposit and the surrounding area suggests that the two generations of quartz + sulphide veins represent the c-axis of two intersecting M3 mylonitic zones. These two mylonitic zones are represented in the literature as the Flat Lake-Howey Bay Deformation Zone $\left(239^{\circ} / 73^{\circ}\right.$ north veins) and Pipestone BaySt. Paul Bay Deformation Zone $\left(119^{\circ} / 76^{\circ}\right.$ south veins).

\section{Cilicia Basin: imaging of salt tectonics in a sedimentary basin in the eastern Mediterranean Sea}

Brian D. Rex

\section{Department of Earth Sciences, Memorial University of Newfoundland, St. John's, Newfoundland AIB 3X5, Canada}

The Cilicia-Andala basin is a fore-arc basin within the Cyprus arc, a zone of active plate convergence in the eastern Mediterranean Sea, currently in transition from subduction to collision. The tectonic development of the basin includes distinct as well as combined phases of thrusting, strike slip and extension. My thesis will be part of a larger project conducted by a team at MUN (Aksu, Calon, Hall) aimed at understanding the local tectonics of the Cyprus arc in terms of plate margin evolution. My thesis is based on 48 channel seismic reflection data acquired in 1992 by researchers from MUN in a joint effort with the institute of Marine Sciences of Doluz Eylul University, Izmir. The data were acquired in the
Cilicia-Andala basin across a line approximately $100 \mathrm{~km}$ in length from the coast of Turkey towards Cyprus.

Many of the structural features of this basin are linked to the interaction of the basement tectonics with a rapidly prograding continental shelf building. Extension of this unstable shelf is evident in gravity sliding with sediment from the Plio-Quaternary above a detachment in the underlying Messinian evaporite layer. This is complemented by salt-cored fold belts in the deeper part of the basin.

The purpose of my thesis is twofold. First, I will use the final processed data in conjunction with that of neighbouring lines to enhance the geological interpretation of the area. Second, 
I will experiment with signal processing techniques, especially multiple removal and migration techniques, to improve the resolution. This component of my thesis will be particu- larly useful in the areas of salt folds where resolution is usually poor.

\title{
A Neoproterozoic history of the Hollow Fault Zone, Antigonish Highlands, Nova Scotia
}

\author{
Jacques Stacey \\ Department of Geology, St. Xavier University, Antigonish, Nova Scotia B2G 2W5, Canada
}

Shear zones commonly have a complex polyphase history. One of the major problems in deciphering their kinematic history is that older movements are overprinted by younger ones. Repeated movements along the Hollow Fault Zone in the northern Antigonish Highlands in the Avalon Terrane of Nova Scotia have resulted in episodes of intense deformation that may range from Neoproterozoic to Mesozoic in age. In the Paleozoic, the Hollow Fault Zone was active during the formation of the Appalachian Orogen and the amalgamation of Pangea, and was probably active during the opening of the Atlantic in the Mesozoic. Its potential Neoproterozoic history, however, is unclear.

Along the Northumberland Strait, detailed mapping and structural analysis of a $500 \mathrm{~m}$ stretch of coastline have identified the preservation of Neoproterozoic fabrics of the Hollow Fault Zone from a time when the Avalon Terrane was located along the periphery of Gondwana, thereby providing a window into kinematics along that continental margin. The study area contains basalt, pelites, and marbles of the Georgeville Group post-kinematically intruded by ca. $610 \mathrm{Ma}$ hornblende gabbro and anorthosite of the Greendale complex. A ductile strike-slip shear zone affects the Georgeville Group host rocks but is truncated by the younger intrusive rocks, indicating that the shear zone is Neoproterozoic in age. S-C fabrics, asymmetric augen structures, small folds, and mineralized extensional fractures within the shear zone indicate a predominantly dextral component of shear. This ductile shear is interpreted to be coeval with Neoproterozoic arc-related activity along the periphery of Gondwana. Preservation of these ancient fabrics is attributed to a "pressure shadow" effect produced by the more competent plutonic rocks during progressive regional deformation. Results of the study may also be useful in locating and examining relict fabrics in polyphase shear zones and will contribute to the understanding of Neoproterozoic kinematics along the edge of Gondwana.

\section{Vertebrate and invertebrate trace fossils from the Horton Bluff Formation (Lower Carboniferous) near Avonport, Nova Scotia}

\author{
Donald Wood \\ Department of Geology, Acadia University, Wolfville, Nova Scotia BOP IXO, Canada
}

The Blue Beach and Hurd Creek members of the Horton Bluff Formation (Horton Group) contain a variety of vertebrate and invertebrate trace fossils from Tournaisian sandstone and shale. They are best preserved as convex hyporeliefs on indurated sandstone. The present study is concentrating on fish, amphibian, and certain arthropod traces from the eastern Annapolis Valley region.

Fish swimming too close to the bottom were responsible for sinusoidal traces left by tail, fin, and spine drags. These trails are attributable to the ichnogenus Undichnus Anderson and are found associated with arthropod traces, amphibian footprints, coprolites, fish scales, and Acanthodian fish spines. $U$. britannicus Higgs is represented by two unpaired waves with different amplitudes but similar wavelengths that were produced by caudal and anal fins. $U$. binus Anderson is represented by one set of paired waves produced by pelvic fins. Two additional trails are not attributable to any known ichnospecies. $U$. isp. 2 consists of one or two discontinuous waves, $180^{\circ}$ out of phase with respect to crescent shaped marks that may represent tail and pectoral fin traces. $U$. isp. 3 consists of three sets of paired asymmetric waves bounding an unpaired medial wave. Paired pelvic fins and an anal fin probably made these markings.

Several trackways resembling those of modern and fossil scorpions and spiders are found in association with sinuous trails and other arthropod traces, suggesting that they were made in an aquatic environment. These traces are believed to be the oldest known of their kind in Canada. Most of these trackways are attributable to Paleohelcura Gilmore and consist of 2 to 4 circular or oval pits with or without a medial tail (?) drag mark. P. tridactyla Gilmore consists of alternating groups of 2 or 3 pits arranged in a line so that their long axis is diagonal to a medial tail (?) drag mark. In following with the International Code of Zoological Nomenclature, the trackways may instead be associated with the ichnogenus Protichnites Owen and Diplichnites Dawson. At least one other large form may also be present.

The amphibian traces are being studied at present. They consist of several kinds of footprints and trackways and include rare tail drag marks. These traces may represent the only Tournaisian amphibian tracks in the world, and the oldest of the most diverse amphibian material ever reported. 